\title{
Existence of Golkar Party in Banggai Regency 1999-2009
}

\author{
Fathur Rahman \\ Department of Governmental Studies, \\ University of Brawijaya \\ Malang, Indonesia \\ fathur1928@gmail.com
}

\author{
Mohtar Haboddin \\ Department of Governmental Studies, \\ University of Brawijaya \\ Malang, Indonesia \\ Nur Rosalia Juita Tahwali \\ Department of Governmental Studies, \\ University of Brawijaya \\ Malang, Indonesia
}

\begin{abstract}
Golkar Party had become the rulling party in Banggai District for ten years starting from 1999-2009. The fantastic victory achieved by the Golkar Party was about 58 percent of the vote in 1999, followed by 32.78 percent in 2004, and then 37 percent votes in 2009. Banggai District has become a granary for the Golkar Party. Therefore, it is not surprising that Golkar Party has solidly demonstrated its existence in both legislative and executive institutions for ten years. This article aims to describe the Golkar Party's strategies in maintaining its existence in Banggai District since 1999-2009. Data were obtained through interviews, documentation and literature study. The results of this study include: First, Mass Basis; Second, the selection of cadres; Third, the relation of Golkar Party with socialorganizations that become the foundation for strengthening its existence in Banggai Regency. The sub-districts were used as the basis of the masses other than placing the Golkar Party cadres as sub-district heads. Tribal politics, identity, cadres became networks to gain votes. The construction business network of Golkar Party cadres has become an economic power for Golkar Party. Finally, the organizationKarangtaruna, KNPI, SOKSI, KOSGORO, and FKPPI become an instrument also in the cadres. Therefore, Golkar Party had become a hegemonic party in Banggai District from 199-2009.
\end{abstract}

Keywords-Existence; Golkar Party; Banggai Regency

\section{INTRODUCTION}

GolonganKarya (Golkar) was established in 1964. Golkar became theengine of the New Order lytic in dominating the political system in Indonesia. After the collapse of the New Order regime in 1998, Golkar's image continues to deteriorate. Now Golkar or Golkar Party still exists in Indonesian politics. Similarly, this happens in Banggai Regency. Golkar Party, since the legislative elections from 1999 to 2009, has always [1]won.

Banggai regency is one of the prominent districtand granary for Golkar's vote in the province of Central Sulawesi. This is evident from the Banggai's legislative elections voting results in the district legislature in 1999 , 2004 and 2009. In the 1999 legislative election, Golkar Party won 22 seats in the House of Representatives (DPRD) of the total 40 seats, then,in 2004 Golkar Party gained 13 seats of the total 30 seats in Banggai Parliament. This means that Golkar Party is the winner of thelegislative election in DPRD with the highest amount. As for the other parties in 1999 like PDIP, they only gained six seats, and PBB with twoseats. This continues for the 2004 period in which PDIP won 4 seats and three seats for Democrats. Golkar Party has sustained its victory in the next period. In 2009, Golkar Party became the winner of the legislative election again, with the acquisition of 6 seats in the Banggai Regency DPRD,whichwas followed by PDIP in second place with five seats. In thethird position was the Democratic Party with the acquisition of 3 seats.

Golkar Party's power is not only the in the legislative but also on the executive. During the past ten years, from 1999 to 2009, Golkar Party's cadres have managed to put in the position of Chairman of Parliament and Head of the Banggai Regency for three periods. Thus, Golkar Party has increasingly controlled politics in Banggai Regency.

\section{RESEARCH METHODS}

The type of research conducted is qualitative descriptive. The qualitative descriptive study is very appropriate for this study, in which researchers seek to describe and answer the reality and the present of the Golkar Party hegemony in Banggai from 1999-2009. Qualitative research methods as revealed by Sugiyono is the research methods used to examine the condition of the object of science, where researchers are a key instrument, data collection technique was done triangulated (combined), data analysis is inductive and qualitative research results further emphasize and generalize[1]. 


\section{RESULTS AND DISCUSSION}

\section{A. The existence of Golkar Party; s victory in Banggai Year} 1999-2009

The Golkar Party has always won the votes in Election are (Dapil) in Banggai from 1999-2009. The existence of the Golkar Party is achieved through several strategies as follows:

\section{1) Mass-Based}

Golkar Party has many mass bases, many outside of Java Island. As stated by SyamsuddinHaris, Golkar is a big national party, regarding cross-culture and ideology, despite its main supporters remain outside Java and parts of West Java and Banten[2].Central Sulawesi in particular Banggai, have manyGolkar masses reaching the districts and villages. Also, according toGianie[3], the Golkar Party's experience can penetrate various social strata, ethnic, cultural, or religious society. This is one factor Golkar Party always wins theelection in Banggai.

Ethnic diversity Banggai affects the elections in Banggai, both the national election and the legislative elections. Issues relating to ethnicity are often used to obtain the support of the community. In this case, the Golkar Party in Banggai also takes advantage of this tribal issue as one of their strategy in the election. ${ }^{1}$ It is also similar to what happened in South Sulawesi, as expressed by Gianie[4]ethnicity and general persona strongly influence voting behaviour in Sulawesi society, including South Sulawesi. As ethnicitysignificantly affects Banggai's choice in elections, it makes Golkar Party in Banggai very selective in choosing cadres in every national election and the legislative elections. One example is by looking at the Banggai Regency DPRD. Chairman of Parliament of Banggai district from the period of 1999, 2004 and 2009, is chaired by the Golkar Party cadres like DjarunSibay,aSaluan, and SamsulBahriMang who is a mixture Saluan and Bugis. 2004

a) Golkar Party Mass Base for the period of 1999-

Here is the strategy of the Golkar Party in the period 1999-2004 seen from the formation of tribes in the Golkar Party faction in Banggai and percentage of Banggai votes at 1999-2004 (Table I).

The data presented in Table I describes the Golkar Party's win with a total of 14 sub-districts among the other parties. On the other hand, Golkar Party's huge successin Banggai amid the distortion of the partycannotbe separated from the history of the New Order for 32 years. Where Golkardepoliticized the masses systemically, i.e.Golkar was free to recruit to the level of the hierarchy within the administration at the bottom, starting from the central bureaucracy down to the village. This was effective and efficient in mobilizing support for Golkar[5].Therefore, after the collapse of the New Order, Golkar Party's cadres

${ }^{1}$ Based on the interview with Muhajirin, a Banggai Regency activist via phoneon 10/07/2015 established since its creation was very stable in governmental and political organizations, particularly in Banggai.This is as revealed by Darwis ${ }^{2}$ as follows: Darwis revealed that there are two things that causeGolkar Party to be a hegemonic party. The first factor is the cadre's potential, the quality of the cadres is higher than other parties, and the cadres have amoresophisticated financial capability. Secondly, the party system is highly structured with a very powerfulGolkar command. Chairman of DPW Province is Prof. AminuddinPonulele; this effect is very strong to instilhow Golkar including Banggai is solid, this solidity is further supported by the quality and finance.

TABLE I. Vote Result OF BANGGAi REGENCY 1999

\begin{tabular}{|c|c|c|c|c|}
\hline No. & Sub-Districts & $\begin{array}{c}\text { Golkar } \\
\text { Party }\end{array}$ & PDIP & PPP \\
\hline 1. & Labobo Bangkurung $^{\mathrm{a}}$ & 70.5 & 11.3 & 6.6 \\
\hline 2. & Banggai & 66.3 & 9.5 & 7.8 \\
\hline 3. & Totikum & 68.5 & 7.9 & 6.9 \\
\hline 4. & Tinangkung & 69.6 & 7.2 & 10.1 \\
\hline 5. & Liang & 71.4 & 5.9 & 3.9 \\
\hline 6. & Bulagi & 60.6 & 15.6 & 2.6 \\
\hline 7. & Buko & 66.9 & 11.2 & 2.9 \\
\hline 8. & Batui & 53.2 & 17.5 & 9.9 \\
\hline 9. & Bunta & 44.6 & 16.9 & 14.7 \\
\hline 10. & Kintom & 53.4 & 11.4 & 6.4 \\
\hline 11. & Luwuk & 53.7 & 15.4 & 6.5 \\
\hline 12. & Pagimana & 58 & 11 & 10.3 \\
\hline 13. & Lamala & 46.3 & 27.5 & 3.3 \\
\hline 14. & Balantak & 51.1 & 14.4 & 5.2 \\
\hline 15. & Toili & 35.1 & 40 & 6.3 \\
\hline
\end{tabular}

Another main strategy utilized by Golkar Party is the strength and persona of cadres who ran as candidates for the legislature. It is similar to what is happening in West Sulawesi; political parties are not the only machine to be the proponent of victory. Politicalhistory and kinship ties are still strong in determining votes; it is these factors that are then a determinant in the direction of public opinion in the political sphere[6]. Voter behaviour can be seen through the three approaches based on Leo Agustino and Muhammad AgusYusoft[7];

"First, sociological approach, this is related to socioeconomic status (such as education, occupation, income and class), religion, ethnicity, and also residence

${ }^{2}$ Interview result with Darwis, a Master Program lecturer of Public AdiministrationTadulako, in a coffee shop in front of the Palu mayor's office in Central Sulawesi on 20/09/2014 ${ }^{3}$ Kompas Researchand Development Team.Opcit. Pg. 621 
(e.g. city, village, coastal or inland). Second, the psychological approach. This approach sees that voter behaviour is determined by how often the socialization of political parties is done, but it also depends on the social interaction that is built and the factors related to their environment. Third, the rational choice approach, rational voters will tend to vote based on economic calculations or in other words by profit - or loss. In this case, the rational voters will choose candidates based on the vision and mission as well as programs offered by the candidates ".

Based on the understanding in on voter behaviour of Banggai society, it is leaning towards the sociological approach. This is seen from the influence of ethnicity in determining people's choice of candidates for the election, as evidenced by the 22 cadres of Golkar Party in Banggai district legislature in 1999, where the majority of them were from the Saluan tribe. Saluan tribe is the biggest tribe settling in Banggai, so that from a total of 22 cadres of Golkar Party in parliament, 11 were from the Saluan tribe, 6 of them are Bugis, three people from the Balantak tribe, one person from the Java tribe, and 1 other person is of Chinese descendant who is an entrepreneur. ${ }^{4}$

\section{b) Golkar Party Mass Base 2004-2009 period}

Here is the strategy of the Golkar Party in the period 2004-2009 seen from the formation of tribes in the Golkar Party faction in Banggai and percentage of Banggai votes at 2004-2009:

TABLE II. ReSUlts of BANGGAi REGENCY ELECTION RESUlTs 2004

\begin{tabular}{|l|l|l|l|l|}
\hline No. & \multicolumn{1}{|c|}{ Sub-District } & $\begin{array}{c}\text { Golkar } \\
\text { Party }\end{array}$ & \multicolumn{1}{|c|}{ PDIP } & $\begin{array}{c}\text { Demokratic } \\
\text { Party }\end{array}$ \\
\hline 1. & Luwuk $^{\text {b }}$ & 39.93 & 13.75 & 4.75 \\
\hline 2. & Lamala & 48.58 & 18.32 & 4.56 \\
\hline 3. & Balantak & 37.01 & 16.08 & 1.35 \\
\hline 4. & Kintom & 23.54 & 23.54 & 7.29 \\
\hline 5. & Batui & 50.1 & 50.01 & 1.22 \\
\hline 6. & Toili & 46.13 & 46.13 & 3.96 \\
\hline 7. & Bunta & 28.36 & 28.36 & 19.99 \\
\hline 8. & Pagimana & 20.76 & 20.78 & 9.56 \\
\hline 9. & Bualemo & 36.61 & 36.61 & 8.92 \\
\hline
\end{tabular}

Based on Table II in the year 2004, there is a change in the electoral district of Banggai. In 2004, there was a fluctuation on the Golkar Party vote where it declined compared to $1999 .{ }^{5}$ One reason for the Golkar Party vote decline was due to the widening of the Banggai area consisting ofLaboboBangkurung, Banggai, Totiku,

${ }^{4}$ Based on chitchats with Ibu Haya, Ibu Bilma, Ibu Ros, Ibu Yuli in the administration department in DPRD Secretariat Banggai Regency, on 01/08/2015

${ }^{5}$ Banggai DistrictElectionCommission
Tinangkung, Liang, Bulagi, and Buko which constitute the majority of supporters of the Golkar Party in 1999. The arrival of a new vigorous competitor of Democratic Party also affects the decline of the Golkar Party votes.

In 2004, there was a shift in voter behaviour, in which voters were between three approaches either approaches: sociological, psychological, and rational. However, the direction of the shift to this rational approach is more likely to be pragmatically rational,although it can not be denied tribal issues are also still a factor in the election of Golkar Party cadres in Banggai district parliament.Thisis evidenced from the 13 Golkar Party cadres with seats in the parliament, where six were from the Saluan tribe, four from Bugis, one from Bali, one from Gorontalo, and one person from the Balantak tribe. ${ }^{6}$ Also, the Golkar Party also expects old voters to provide votes for the Golkar Party. Some traditional voters who voted for Golkar and Golkar Party's success in placing cadres go in line with their constituency area, where the -cadres have their selling power to the community both regarding persona or figures, as well as thetribal base. ${ }^{7}$

Other strategies used by Golkar Party to win nine districts in Banggai is through emotional approach. On table I, it explains that in 1999 the Toili district that has a Javanese and Balinese majority chose PDIP Party in 1999, but in 2004, chose the Golkar Party.

\section{c) Golkar Party Mass Base period 2009-2014}

Here is the strategy of the Golkar Party in the period 2004-2009 seen from the formation of tribes in Golkar Party faction in Banggai and percentage of Banggai votes in 2004-2009:

TABLE III. RESUlts OF BANGGAI REGENCY ELECTION RESUlT 2009

\begin{tabular}{|l|l|l|l|l|}
\hline No. & \multicolumn{1}{|c|}{ Sub-District } & $\begin{array}{c}\text { Golkar } \\
\text { Party }\end{array}$ & \multicolumn{1}{|c|}{ PDIP } & $\begin{array}{c}\text { Demokratic } \\
\text { Party }\end{array}$ \\
\hline 1. & Luwuk $^{c}$ & 16.91 & 5.33 & 8.35 \\
\hline 2. & Luwuk Timur & 17.77 & 5.64 & 4.22 \\
\hline 3. & Masama & 14.6 & 4.33 & 3.96 \\
\hline 4. & Lamala & 11.92 & 11.25 & 5.78 \\
\hline 5. & Balantak & 14.09 & 7.84 & 5.96 \\
\hline 6. & Kintom & 9.53 & 8.2 & 10.45 \\
\hline 7. & Batui & 13.21 & 20.01 & 5.66 \\
\hline 8. & Toili & 7.84 & 24.03 & 13.5 \\
\hline 9. & Toili Barat & 3.3 & 15.89 & 3.28 \\
\hline & & c. Source: Banggai District Election Commission
\end{tabular}

${ }^{6}$ Based on chitchat with Ibu Haya, Head of the legislation Secretariat DPRD of Banggai Regency on 15/08/2015 ${ }^{7}$ Based on an interview with SukriDjalumang, Chairman of Golkar Party 2010 - 2015 in his house on 06/09/2014 
Based on Table III, in 2009 there is a change in the Banggai electoral district, due to thewidening of the Banggai region. Dapil I includesLuwuk East Luwuk, Masama, Lamala, and Balantak. Dapil II includesKintom, Batui, Toili, and Toili West. Dapil III includesPagimana, Bunta, Nuhon, and Bualemo.Based on the figures presented in Table III above, the Golkar Party experienced a very drastic decline of votes, and the Golkar Party's victory number was very close to the PDIP victory figure.

Golkar Party, who usually won almost all its districts lost its mass bases, such as Batui and Toili districts. Both sub-districts shifted their voting choices to PDIP. It is also related to the internal conflict of the Golkar Party where Herwin Yatim, previously a Golkar Party cadre was fired and eventually became Chairman of PDIP. Moreover, the entry of new political parties in Banggai such as Gerindra and Hanura also affects the voting reduction of the Golkar Party.

In the 2009 election, Golkar Party used the financial strength Golkar cadres in the election, although tribe and kinship are still the strong the strategy indicator of the Golkar Party.SukriDjalumangthat, the elected Golkar Party cadre as the member of Parliament period 2009-2014 from theelectoral district I, is the candidate with the most votes in the electoral district with as many as in 2164 votes.

Of the three existing electoral regions in Banggai district, this is the hardest electoral district in Banggai as candidates with over 2000 votes are rare. Difficulties to win votes in the electoral district is not only felt by the Golkar Party but also other parties. This is because Luwuk is the capital of Banggai and people tend to have a rational voting behaviour, and persona and tribe not very influential in the region.

Nonetheless, SukriDjalumang won the most votes in this electoral district. Even SukriDjalumang won the most votes in Banggai. This is due to his public figure, and becauseSukriDjalumangpossesses theconsiderable financial strength to sustain his political activities. Based on information achieved before the election and during the election, SukriDjalumang is a very generous person. Each funding proposal from organization brought to him by the local communities was always given. There was one event where a group of people come in asking for help procuring four ships, SukriDjalumanggives as many as eight ships.

Not only that, during the campaign, SukriDjalumang spent more money when visiting the districts and the community than the other candidates. During the voting, SukriDjalumanggave not only money but also food, and one pack cigarettes are distributed to everyone. ${ }^{8}$ Also, SamsulBahriMang as Chairman of the Golkar Party and the Chairman of the Parliament the period 2009 to 2014 also declares that:

"We help all the communities, and we approach their activities, we do not leave them, we support their needs if

${ }^{8}$ Based on an interview with Muhajirin Alzahra, a Banggai Regency activist in a café in Teluk Lalongon 30/07/2015 we can and participate with them, community organizations, youth groups, NGOs, sometimes unnamed organizations may hold volleyball activities, and we still assist, so they can always remember the Golkar Party ". 9

Elected politicians in Dapil II have the most votes in the electoral district, based on information, they spent considerable money on the election of 2009. Also, its popularity background is mainly from his tribe and persona that supported SamsulBahriMang for his winning the 2009 election. Based on the information received, explains that every Golkar campaign, both national and legislative, the Golkar Party has always said that the programs and help given to the public is from the Golkar Party, even the government assistance for the community is recognized as being from the Golkar Party, ranging from road construction, fertilizer and so forth.

\section{2) Cadre Selection}

In electing Golkar Party cadres, there are several elements required of the individual when assuming the role of the Golkar Party elite and also as legislative candidates from the Golkar Party. Tese elements are as follows: First, the Economic Power. This element is very influential according to the researchers, Golkar Party cadres have a stable economy for both the executive and legislative branches. In average, elected Golkar Party legislative politician in Banggai Regency is a contractor or businessman. While the executive position, like the Regent, has an established economic background. Also, the cadres of the Golkar Party branch organization with a position like Head of Service in Banggai Regency must also have economic power. Moreover, if the Golkar Party cadres already in the circle of the Golkar Party elite, their finance affects their ability to maintain their position as an important office holder in the party.

Second, the Network Organization. This element is owned by almost every cadre of Golkar Party. Social organizationshave primary responsibility for establishing anetworkwithcommunity groups, encourage community participation, and promote the interests of the community[8]. Golkar elites in Banggai are already clearly linked to organizations in Banggai society. This connection can be useful to mobilize the masses for support when the national and legislative election. Third, elite persona. Most Golkar Party cadres are community leaders of Banggai, be it of the youth leaders, traditional leaders, and entrepreneurs. Persona is also important for Golkar politicians. As quoted by Ganie [3], a political analyst of UniversitasHasanuddinKausarBailusy revealed that:

"The one who leads Golkar in South Sulawesi is dominantly nobles. These nobles, when occupying strategic positions, will be able to influence the masses who still firmly adhere to local values. The people of South Sulawesi

${ }^{9}$ Based on an interview with Samsul Bahri Mang in his house as Chairman of the Banggai Regency DPRD on $23 / 10 / 2014$ 
will adopt the ideals of the people who become their role models. Therefore, choosing not his consciousness, but following the choice of his character".

Furthermore, Ganie also revealed in the culture of South Sulawesi;political choices will indeed be influenced by persona. These personas embody figures from a nobleman to landowners who provide alivelihood for the community[3].

Fourth, Ethnicity. Arnold Andreas Nababan[9]explains that the socio-cultural structures ethnicity impact significantly in society affecting the social order itself. Tribal / Ethnicity is used to accommodate the voice on the national and legislative. Here is a list of name of the core committee of the Golkar Party Banggai district from 1999 to 2015:

TABLE IV. ORGANIZATIONAL STRUCTURE FORMAT OF GOLKAR PARTY OF BANGGAI REGENCY

\begin{tabular}{|c|c|c|}
\hline \multicolumn{3}{|c|}{ Periode } \\
\hline $1998-2003$ & 2003-2007, 2007-2009 & $2010-2015$ \\
\hline $\begin{array}{l}\text { Chairman: Djarun } \\
\text { Sibay }^{\mathrm{d}}\end{array}$ & Chairman : Djarun Sibay & $\begin{array}{l}\text { Chairman : Samsul } \\
\text { Bahri Mang }\end{array}$ \\
\hline $\begin{array}{ll}\text { Secretary : Yusuf } \\
\text { Djalil }\end{array}$ & Secretary : Yusuf Djalil & $\begin{array}{l}\text { Chairman Harian : } \\
\text { Sukri Djalumang }\end{array}$ \\
\hline $\begin{array}{l}\text { Treasurer:YoristonK } \\
\text { osworo }\end{array}$ & $\begin{array}{l}\text { Treasurer:YoristonKoswo } \\
\text { ro }\end{array}$ & $\begin{array}{l}\text { Secretary: Arifin } \\
\text { Morintoh }\end{array}$ \\
\hline & & $\begin{array}{l}\text { Treasurer: Sulianti } \\
\text { Murad }\end{array}$ \\
\hline
\end{tabular}

d. Source: Interview Results Reconstruction

Based on Table IV above DjarunSibay is a former Chairman of KNPI, he also served as Head of Department in Banggai, served as Camat in Batui. DjarunSibay also served as Chairman of the Parliament from 1999 - 2004 and 2004 2009. Is a native of the Saluan tribe, and has a network of organizations with Luwuk and Maahas Family.

Yusuf Djalil is one of the quite charismatic community leaders were inBanggai, served as a member of Parliament Banggai from 1999 - 2004, previously served as the Head of Department. $\mathrm{He}$ is a mixture of Saluan and Banjar. YoristonKhosworo is an entrepreneur who has succeeded and is famous in Banggaidistrict; his business is in the shrimp and fish industry in Batui, he is of Chinese descendants. He is also the only member of the Golkar Party and the ethnic Chinese elite to fill positions in the Golkar Party, as 1999 rarely saw Chinese filling the elite position in the Golkar Party. SamsulBahriMang is the son of a former leader of the Golkar Party in the pre-reform era, Majid Mang. SamsulBahriManghas family ties with former Regent DartoBanggai, who served as Deputy Governor of Central Sulawesi. He is of Baluan and Bugis tribe and is a famous youth leader in Banggaidistrict; he is in the field of contracting. Before serving in the legislative, SamsulBahriMang had no contracting business, but after his position, he then went into contracting. It also has a network of organizations with Youths Karatons (GMK) and Youth Committee Karatons (KPK), the two organizations have a high degree of popularity in Luwuk city.
SukriDjalumang is a moderately successful contractor in Banggai, and has a network with youth kilo one, and is from the Saluan tribe. The Djalumangs is also a well-known family in Banggai as they often occupy public positions such as thehead of department or agency heads in Banggai.

ArifinMorintoh has businesses located in Pagimana and Balantak in the plantation sector; he is of Saluan tribe and a former influential activist Banggai in the post-reform era. Sulianti Murad is a businessman who is the son of Murad Husain, the largest palm oil businessman in Banggai District. Sulianti Murad is the successor of PT.KLS ${ }^{10}$. The Murad family hasassets not only on the plantation but also on the field of tourist attractions and entertainment.

\section{B. Golkar Party Relation with Social Organization}

The New Order not only inherited a strong structure for Golkar Party, both organizationally and the people within the government but also outside of the government. The political machine of Golkar Party in the New Order mastered almost all sectors of the public, whether it be government and non-government. Thisis reflected in the Reformation era where civil society has since grown, the trend of civil society attracted a lot of interest among many ranging from academics, scholars, cultural, and student activist movement, to politicians[10].

Gramsci viewed civil society as a part controlled by a political society, derived from a particular group where "civil society" is monopolized, thus becoming the power base of a particular group. Gramsci also stressed in certain communities that do not belong to a party / do not organize[11].Based on this regard, civil society has a role in supporting the political force in countries. It is also explained by Adi Suryadi Culla that both society organizations, anorganization of social and nongovernmental organizationsare also included in the circle of civil society[10].

Golkar Party through its founders: MKGR, Kosgoro, Soksi. The three organizations are founding organizations of the Golkar Party, which continue to function from the New Order era to the present. The office of these three organization can be found even subdistricts or villages in Banggai. Although the post-reform era eliminated the principle of monoloyality, but civil servants, especially in Banggai district, are still incorporated in the three organizations, especially MKGR. Even some Heads of Service in Banggai District have important positions in the three organizations. Also, the Golkar Party also encompass youth in Banggai, mainly former activists in campus to join AMPG wing organizations. Golkar Party's ability to mobilize society organizations in Banggai district itself becomes attractive since the reform era demanded many changes of the system and social order in Indonesia. In 1999 the Golkar Party was superior because it establishes control

${ }^{10} \mathrm{PT}$ Kurnia Luwuk Sejati atau PT KLS is a company that operates in the forestry, contractor and other business. It is located inToili, Singkoyo, Batui village in Banggai District and North Bungku in Morowali district, Central Sulawesi. 
in a social community like KNPI, Youth and FKPPI in Banggai. As revealed by KuskridhoAmbardi[12] KNPI become one of the organizations designed by Golkar Party in the New Order to round-up youth and student activists. These three organizations, both KNPI, KarangTaruna, and FKKPI do have a large mass in Banggai District. Many young people and student activists of Banggai District are incorporated in them. Important positions in those organization are held by the Golkar Party cadres, even the helm of the three organizations are filled by Golkar Party elites, one example is Djar'unSibay. However, since 2005 support for these organizations, and ultimately the Golkar Party, in Banggai regency began to decline, this is because other parties in the political arena in Banggai tried to shift the key positions of the Golkar Party cadres in those three organizations. ${ }^{11}$ However, in 2011, the Golkar Party support base began to grow from religious groups namely $\mathrm{Al}$ Khairat.

\section{CONCLUSION}

In practice, the hegemony of Golkar Party in Banggai Regency is reflected from Golkar Party's relationship with various elements of the power source in Banggai Regency. Based on the results of Golkar Party's research on the legislative authority, it is seen from; First, the ideological distance of Golkar Party with other parties. Golkar Party tolerates the existence of parties with different ideological distance with Golkar: PDIP Party, PAN, PKS, PKB, PPP, Hanura, Democrats, but does not have a big enough effect to match the party. Second, the Golkar Party Satellite Party. The Golkar Party allowed the second party parties (PDIP, PAN, PKS, PKB, PPP, Hanura Party, Democratic Party) to obtain administrative, parliamentary and governmental positions, but the power provided was so small that the main force remained in the Golkar Party.

\section{References}

[1] Sugiyono, Metode Penelitian Kuantitatif, Kualitatif, dan $R \& D$. Bandung: Alfabeta, 2013.

[2] S. Haris, Partai, Pemilu, dan Parlemen Era Reformasi. Jakarta: Yayasan Pustaka Obor Indonesia, 2014.

[3] Gianie, "South Sulawesi," in Kompas 27 Februari 2009, ed, 2009.

[4] Gianie, "Paduan Etnisitas di Kancah Politik," in Kompas, 23 February 2009, ed, 2009.

[5] A. Gaffar, Javanese Voters: A Case of Election Under a Hegemonic Party System. Yogyakarta: Gajah Mada University Press 1992.

[6] Sugihandri, "Sulawesi Barat," in Kompas 24 February 2009, ed, 2009.

[7] L. Agustino and M. A. Yusoft, "Pemilihan Umum dan Perilaku Pemilih: Analisis Pemilihan Presiden 2009 di Indonesia," Jurnal Kajian Politik dan Masalah Pembangunan, vol. 5, no. 1, 2009.

[8] D. Triwibowo, Gerakan Sosial Wahana Civil Society bagi Demokratisasi. Jakarta: Pustaka LP3ES, 2006.

${ }^{11}$ Based on an interview with Iskandar Djiada, Harian Media Banggai journalist, in thefoodcourt of Luwuk Shopping Mallon 06/06/2015
[9] A. A. Nababan, "Demokrasi Lokal dan Politik Etnisitas Batak : Kajian Basis Massa Anggota DPRD Provinsi Jawa Timur Etnis Batak," Jurnal Politik Muda, vol. 4, no. 2, 2015.

[10] A. S. Culla, Rekronstruksi Civil Society : Wacana dan Aksi Ornop di Indonesia Jakarta: Pustaka LP3ES, 2006.

[11] A. Gramsci, Prison Notesbook. Yogyakarta: Pustaka Pelajar, 2011

[12] Ambardi and Kuskridho, Mengungkap Politik Kartel, Studi Tentang Sistem Kepartaian Era Reformasi Jakarta:PT.Gramedia,2009 